THURSDAY, MAY I2, 1870

\section{A BUILDING FOR THE LEARNED SOCIETIES}

THE Statistical Society has done good service to the cause of science in convening representatives of the learned societies, to consider whether it would not be possible to obtain a building for their accommodation worthy of the high position they occupy in this great metropolis. At this moment several societies are under notice to quit, others scarcely know where to look for shelter, and many more are utterly unable to find sufficient room for their libraries, instruments, and museums, though they pay a large portion of their income in rent and taxes. It is calculated that, jointly, upwards of $2,000 l$. a year is now paid in rent, enough, one would think, if properly managed, to supply most ample accommodation for very many societies, to say nothing of the great economy in service that would result from the joint occupation of a proper building. But so long as nothing is done to bring about some understanding and co-operation among the different societies, the evil is irremediable. Nor is it purely a question of finance. Many abstain from joining a learned society when its place of meeting is either inconveniently situated, or altogether too small for the usual attendance at the ordinary meetings. Not a few members of more than one society are unnecessarily driven from one place to another. The libraries for reference are not half utilised. Co-operation among men of science is almost impossible, and the action of each society is rendered thereby comparatively feeble and ineffective. On every ground, whether of convenience, economy, or utility, the learned societies would do well if they could combine in erecting a building sufficiently capacious for their joint accommodation.

Some learned societies have no reason to complain. The Royal Society, the Linnean, the Royal Astronomical, the Geological, the Chemical, the Society of Antiquaries, and a few others, are well accommodated, and a solid structure is being raised for them in Piccadilly. Those whose wants are yet to be supplied are the Statistical Society, the Institute of Actuaries, the Mathematical, Meteorological, Ethnological, Anthropological, Geographical, Archæological, and Juridical Societies, the Social Science Association, and as many more; and it is for them to consider whether it is better to go on as they are doing, paying one, two, or four hundred pounds a year each for their present rooms, or whether they would not do better by combining together for the erection of a proper building for them all. In calculating how many societies could unite for such a purpose, we must take into account the kindred character of their labour and inquiries. The statisticians, actuaries, and mathematicians might well meet together, and so it would be fitting that the antiquaries and archæologists should have a common habitation. But not so those that have nothing in common. Then the number of members and the space required for meetings, libraries, and museums are important elements. The Geographical Society, with its maprooms and extensive library, would require space enough for a dozen other societies. And further, the frequency of meetings must be considered, when at the most only three or four commodious halls could be secured in any one building. We scarcely imagine, in fact, that any large number of societies could well be united in one building, and that will be a source of difficulty, especially in a financial aspect.

But why should there be any financial difficulty? Surely the erection of one or more buildings for purposes of science is a duty which may well rest with the Government. Nowhere does the State do so little for science as in this country. The estimates for $1870-71$ give the entire sum to be applied to the learned societies at $2,370 l$. - a sum distributed among very few of them. Of this 5ool. goes to the Royal Geographical Society, to provide suitable rooms in which to hold their meetings, and to exhibit to the public, free of charge, their collection of maps; $300 l$. is given to the Royal Society of Edinburgh; 500 . to the Royal Academy of Music; and $70 l$. to the Irish Academy of Music. In addition to this Ió,oool. are appropriated to a building for certain learned societies in Burlington House; but it will serve for very few of them; and if we are rightly informed, the Government will reoccupy all the buildings in Somerset House now used by learned societies.

The chairman of the meeting at the Statistical Society stated that communications had passed between himself and the Chancellor of the Exchequer, and that no encouragement whatever was given for any application of this nature. But it is the clear duty of the societies not to rest satisfied with this, but to get a decided expression of opinion on the subject. By no means should the most natural and proper channel for obtaining the requisite sum for a building so essential to the well-being of the country be neglected.

But supposing the Government should turn a deaf ear to the application of the learned societies, are there no means available within these bodies themselves for getting the amount? It has been estimated that the probable cost of a building sufficiently commodious, though not ornamental, in some eligible locality near Charing-cross, will be, with the ground-rent, 30,000l. to $40,000 \%$. Why should not a joint-stock company be formed for the purpose, and a large number of shares be taken up by the members of the societies interested? Some societies have moreover an accumulated fund of considerable importance. The Geographical Society has, it is understood, upwards of $20,000 l$. What more natural than to apply such investments in a palace of science, with an income so well guaranteed by the rental of the learned societies? The financial part of the question must be carefully but fearlessly approached. No insurmountable difficulties stand in the way of obtaining any reasonable amount for such a purpose.

What we want is a prompt and vigorous action on the part of the learned bodies. Heaven helps those who help themselves. The delegates at the meeting at the Statistical Society unanimously resolved in favour of co-operation on the subject, but by an unfortunate introduction of too cautious a spirit, they let the opportunity slip without naming a committee to prosecute the necessary inquiries and to digest a suitable scheme. Such a committee could not have committed the partics to any course of action. Its object would have been to place the proposal on a practical basis, so as to 
enable the societies to come to a right decision. As it is, the Conference decided to invite the societiesfirst, to confirm by their separate vote the joint resolve of their delegates, and then to give proof of their interest in the attainment of the object by nominating one or more members to act on a committee to be appointed for the purpose. The evil of such a course is, that much valuable time is lost in correspondence and negotiation before any practical step is taken in the matter. After all, however, the delay may be useful in ripening opinion on the subject. What is wanted in the steps eventually to be taken is energy of purpose and promptitude of action, for we are sure that the object in view will be eminently conducive to the welfare and progress of Science in the United Kingdom.

\section{FOSSIL OYSTERS}

Monographie du Genre Ostrea-Terrain Cretacé. Par Henri Coquand, Docteur és-Sciences, Professeur de Geologie et Mineralogie. (Paris : Baillì̀re, I 869.)

F the many able geologists whom France has produced, few have had better opportunities of observation, or have availed themselves of them to better purpose, than the author of this monograph. Distinguished alike by his skill and long experience as a palæontologist, and by his extensive knowledge of practical geology, $M$. Coquand has laboured long and well, and far and wide-not only in Provence, and Italy, and Germany, but in far distant regions in Spain and Africa, in valleys and mountains never before resounding to the blows of the geologist's hammer.

Those who are only acquainted with the chalk as it is seen exposed in quarries and cuttings on the green downs and wolds of England, can form but a very imperfect notion of its true character. As $M$. Coquand has shown in a paper lately read before the Geological Society of London, * the chalk of England, extensive as we are accustomed to regard it, is but a fragment when compared with that which is seen in the South of France. The utmost thickness of the English Cretaceous beds is found to be about 900 feet, while in Provence the same, or rather the equivalent beds are more than 4,000 feet thick. In England we are accustomed to arrange the chalk into three or four divisions, while in France their more extended development requires an entirely different arrangement, and thus we find no less than eleven different beds, the character and limits of which are now ascertained with great accuracy.

The French strata being thus so much more largely developed than the English, the character of the fauna is, as might be expected, infinitely more varied. The difference of nearly three thousand feet is principally represented in France by several marine and freshwater beds altogether unknown in England. In some places, as at La Cadière and Martigues, we find extensive beds of Hippurites and Radiolites-fossils almost unknown in England, lying ranged in close order as when they lived; and again, while we have been accustomed to regard the chalk as altogether of marine origin, we find in Provence a district of about 250 square miles, in which the upper chalk strata of England and the Charentes of France are represented by freshwater deposits $I, 400$ feet thick. These contain several hundred species of land and fresh-

* Quarterly Journal G. S., Aug. 1869, vel, 25, part 3 . water shells unknown elsewhere, associated with beds of lignite as compact as our own Newcastle coal, and like it worked extensively for fuel. Both from the palæontological and the geological evidence it would seem as if, at some time, while our Cretaceous deposits were interrupted and stationary, others of great magnitude, with a succession of fauna essentially differing, as well from our own as from each other, were accumulating in the South of France, alternately depressed and elevated-sometimes a deep sea, sometimes a great lake, and not improbably at one time dry land.

After a careful study of the Cretaceous systems of many countries, M. Coquand, undeterred by the dread of taking charge of a family at once so numerous and so troublesome, has now been induced to prepare this monograph of all the Cretaceous oysters wherever found, to be followed by like monographs of the Tertiary, Jurassic, Triassic, and Permian formations. It is, we believe, the first, or at least the most important attempt to give a synopsis of any one genus occupying so extensive a range.

The results of $M$. Coquand's researches are sufficiently striking; he describes no less than 255 distinct species of chalk oysters (including Gryphæa and Exogyra), and of these he has given excellent figures in an atlas of 75 plates, in folio. As regards England, he has disclosed the poverty of the land as compared with our neighbours. Our chalk oyster beds have been examined as assiduously as the French, but they have been found much less prolific, While France possesses I 5 well-marked species, England. according to Mr. Morris's catalogue, can show but 25, all of which, except one (O. triangularis of Woodward), seem to be found also in France.

Nor is the range of some species less remarkable than their abundance. Two of them (vesiculosa, and ungulata or larva) appear to be altogether cosmopolitan ; the former being found alike in England, France, Algeria, Belgium, Spain, Poland, Russia, Sweden, North America, and Mexico; and the latter having been also traced through all these countries (except Poland and Mexico), and extending its range also to India.

But while some species are thus prone to wander, others are to be noted for their domestic habits. Out of 49 American species, five only have been met with in Europe; and of 27 in Russia, and 23 in Spain, no less than to in each of these countries are not found elsewhere.

It seems evident from our author's observations, that so far as these fossils are concerned the several zones of chalk which he has described are divided by "a hard and fast line," marking the limits of each as clearly as the Tertiaries are separable from the Secondary rocks. Of the several Dordonien species, not one is found in the Campanien beds, and of ninety-five found in the Campanien none are found in the lower beds, and the same observation applies to each of the seven or eight inferior deposits. Although it transcends all our powers of calculation to form even a conjecture, much less an approximate estimate of the ages of ages that should be allowed for the creation (or, if that word be not allowable, for the introduction or evolution) of these various forms, and the extinction of their predecessors, we may yet gather from these materials a somewhat better, although still utterly inadequate notion of the extreme deliberation, so to spcak, exhibitcd in building up this portion of the earth's fabric. 